\title{
Laboratory Investigation on the Short-Term Compressive Strength of Microbial Laterized Concrete
}

\author{
Awolusi T. F., Akinkurolere O. O., Oke O. L.", Adetifa O. A. \\ Civil Engineering Department, Faculty of Engineering, Ekiti State University, Ado-Ekiti, Ekiti State, Nigeria \\ *Corresponding Author: seyioke@hotmail.com
}

Copyright (C) 2013 Horizon Research Publishing All rights reserved.

\begin{abstract}
This study investigates the effect of Bacillus subtilis JC3 on the compressive strength of laterized concrete. Taguchi method of experimental design which involved the use of orthogonal tables with three levels and three factors was employed. In all, 108 samples of $150 \mathrm{~mm} \times 150 \mathrm{~mm} \times 150 \mathrm{~mm}$ concrete cubes cured in two media (water and nutrient broth) with a mix ratio of 1:2:4 were tested for compressive strength at 7, 14 and 28 days. The factors used were water/cement ratio, percentage laterite replacement for fine aggregate and concentration level of bacterial medium (added in different proportions as liquid for mixing the composite material). The results showed that Bacillus Subtilis JC3 generally enhanced the compressive strength and durability of the conventional concrete studied. The observed optimum values for water/cement ratio and bacterial medium for the constitution of concrete were found to be 0.50 and $20 \%$ respectively, however a negative trend was observed for laterite replacement for sand.
\end{abstract}

Keywords Compressive Strength, Water/Cement Ratio, Laterite, Sand, Granite And Bacillus Subtilis JC3

\section{Introduction}

Concrete is a composite material containing - cement, aggregate and water which are added in different proportions based on the desired use. The aggregate is generally coarse gravel or crushed rocks such as limestone, or granite, along with fine aggregate such as sand. Portland cement is commonly used as binder and various chemical admixtures such as fly ash, silica fumes and ground granulated blast furnace can also be added to produce concrete with improved strength and durability [1].

Due to increasing cost of producing concrete using these conventional materials such as cement, river sand as fine aggregate and granite as coarse aggregate in Nigeria, researchers have been working on alternative, cheap and readily available materials that would serve perfect substitutes for such materials while still meeting the set requirements for concrete in the industry. The use of laterite in combination with river sand in particular have received much attention in Nigeria, laterite being a tropical soil that is abundantly available in the tropical belts of the world. This had attracted the interest of researchers both in the time past and in recent times [2-9]. The efforts of these researchers have led to the production of laterized concrete. Salau, [10] defined laterized concrete as concrete in which stable laterite replaces fine aggregate, basically sand. Results of investigations on laterized concrete as reported by most researchers have consistently shown that laterized concrete is inferior in compressive strength and durability when compared to conventional concrete. For this reason, laterized concrete has found little or no application in the Nigerian construction industry.

Generally in the preparation of concrete, the addition of water to its dry constituents brings about chemical reaction between it and cement which is referred to as hydration thereby producing cement gel and Calcium Hydroxide $\left(\mathrm{Ca}(\mathrm{OH})_{2}\right)$. From these products of hydration, $\mathrm{Ca}(\mathrm{OH})_{2}$ most readily react with Carbon IV Oxide $\left(\mathrm{CO}_{2}\right)$ to form Calcium Carbonate $\left(\mathrm{CaCO}_{3}\right)$ with the rate of carbonation of concrete increasing with an increase in concentration of $\mathrm{CO}_{2}$. Carbonation could have some positive consequences because $\mathrm{CaCO}_{3}$ occupies greater volume than $\mathrm{Ca}(\mathrm{OH})_{2}$ which it replaces and in turn reduces the porosity of concrete since it is generally accepted that the durability of concrete is related to the characteristics of its pore structure [11]. An alternative means of making more $\mathrm{CaCO}_{3}$ available to fill more concrete pores is the use of Microbiologically Induced Calcium Carbonate Precipitation (MICCP) resulting from the metabolic activities of some specific micro-organisms embedded in concrete thereby increasing its compressive strength and overall durability.

With recent encouraging reports on compressive strength enhancements achieved in conventional concrete through Microbiologically Induced Calcium Carbonate Precipitation (MICCP), it is envisaged that if such measure is introduced to laterized concrete, its compressive strength could possibly be pushed to a level good enough for various applications in the construction industry. The present work therefore assesses the compressive strength of laterized concrete under the effect of Bacillus Subtilis. 


\section{Materials and Methodology Materials}

The materials used for this experiment were:

- Cement

- Fine Aggregate (Sharp Sand)

- Laterite

- Coarse Aggregate (granite)

- Water

- Nutrient Broth

- Bacillus subtilis JC3 (Bacteria)

\subsection{Cement}

The cement used for this experiment was the Ordinary Portland Cement (OPC) produced by Dangote Cement Company. This met the requirements of BS 12 [12].

\subsection{Fine Aggregate}

Fine aggregates used (sharp sand and laterite) were locally obtained. The gradation curve of the laterite used is as shown in Figure 1.

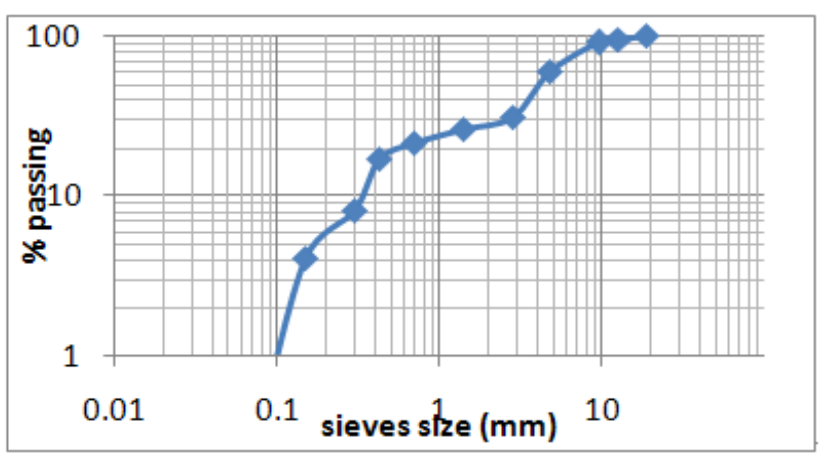

Figure 1. Sieve Analysis for Laterite

The coefficient of uniformity of the laterite used was 15.15 which classified the material as well graded.

\subsection{Coarse Aggregate}

Crushed angular granite from local quarry was used as coarse aggregate in this investigation.

\subsection{Water}

Tap water (potable) was used for mixing and curing during the laboratory investigation.

\subsection{Nutrient Broth}

Biomark nutrient broth commercially available was obtained in a chemical and laboratory equipment shop and used for the laboratory investigation..

\subsection{Bacteria}

Pure cultures (Bacillus Subtilis JC3) were maintained on nutrient agar slants which form irregular dry white colonies on nutrient agar. Whenever required a single colony of the culture was inoculated into nutrient broth of $25 \mathrm{ml}$ in $100 \mathrm{ml}$ conical flask maintained at a temperature of $37^{\circ} \mathrm{C}$ and placed in $125 \mathrm{rpm}$ orbital shaker. Growth was stopped after 48 hours when the concentration of bacteria reached $10^{5}$ cells $/ \mathrm{ml}$ and was preserved at a temperature of $5^{0} \mathrm{C}$ until further use. Reddy et al [13] in their work achieved highest compressive strengths using bacteria concentration of $10^{5} \mathrm{cells} / \mathrm{ml}$ from a wide range of experimented values.

\section{Design of Experiment}

In this work, Taguchi's approach of experimental design was adopted in order to reduce the number of trials required to gather necessary data. An orthogonal array L9, 3 series (as shown in Table 1) was used. The three levels considered which formed the column of the orthogonal array were the water/cement $(\mathrm{w} / \mathrm{c})$ ratios $-0.45,0.50$ and 0.55 , while the test factors on the orthogonal rows considered were the percentage replacement of fine aggregate content with laterite (LAT), the water /cement ratio (W/C) and the changes in the volume of Bacterial medium (BM) which depends on the quantity of water required for each run respectively as shown in Tables 2 and 3 [14].

Table 1. Summary of Test Factors and Levels for OA $\mathrm{L}_{9}$

\begin{tabular}{|c|c|c|c|}
\hline \multirow{2}{*}{ Level } & \multicolumn{3}{|c|}{ Factors } \\
\cline { 2 - 4 } & W/C ratio & Laterite Content & Bacterial medium \\
\hline 1 & 0.45 & $0 \%$ & $10 \%$ \\
\hline 2 & 0.50 & $20 \%$ & $20 \%$ \\
\hline 3 & 0.55 & $40 \%$ & $30 \%$ \\
\hline
\end{tabular}

Table 2. A Three Level Orthogonal Array ( $\mathrm{L}_{9}[3$ series])

\begin{tabular}{|c|c|c|c|}
\hline $\begin{array}{c}\text { Trial } \\
\text { No }\end{array}$ & $\begin{array}{c}\text { Water } / \\
\text { Cement ratio }\end{array}$ & Laterite Content (\%) & $\begin{array}{c}\text { Bacterial } \\
\text { Medium (\%) }\end{array}$ \\
\hline 1 & 1 & 1 & 1 \\
\hline 2 & 1 & 2 & 2 \\
\hline 3 & 1 & 3 & 3 \\
\hline 4 & 2 & 1 & 2 \\
\hline 5 & 2 & 2 & 3 \\
\hline 6 & 2 & 3 & 1 \\
\hline 7 & 3 & 1 & 3 \\
\hline 8 & 3 & 2 & 1 \\
\hline 9 & 3 & 3 & 2 \\
\hline
\end{tabular}

Table 3. Proportion used for the various Mixes

\begin{tabular}{|c|c|c|c|}
\hline $\begin{array}{c}\text { Test } \\
\text { No }\end{array}$ & $\begin{array}{c}\text { Water / Cement } \\
\text { Ratio }\end{array}$ & $\begin{array}{c}\text { Laterite Content } \\
(\%)\end{array}$ & $\begin{array}{c}\text { Bacterial Medium } \\
(\%)\end{array}$ \\
\hline 1 & 0.45 & 0 & 10 \\
\hline 2 & 0.45 & 20 & 20 \\
\hline 3 & 0.45 & 40 & 30 \\
\hline 4 & 0.50 & 0 & 20 \\
\hline 5 & 0.50 & 20 & 30 \\
\hline 6 & 0.50 & 40 & 10 \\
\hline 7 & 0.55 & 0 & 30 \\
\hline 8 & 0.55 & 20 & 10 \\
\hline 9 & 0.55 & 40 & 20 \\
\hline
\end{tabular}




\section{Compressive Strength Test}

To study the compressive strength of laterized concrete, Bacillus sp. JC3 was grown in Nutrient broth medium. The concrete mix ratio was 1:2:4 (batching done by weight), and the bacterial culture/water to cement ratio was varied at 0.45 , 0.50 and 0.55 respectively. A cube mould of $150 \mathrm{~mm}$ was used. The mixing of concrete constituents was carried out with materials being laid in uniform layers, one on the other in the order-coarse aggregate, fine aggregate and cementitious material. Dry mixing is done to obtain a uniform colour. Required amount of bacteria medium was added along with the water. Cubes were cast and compacted with a vibration machine and left in the molds for $24 \mathrm{hrs}$ before de-molding. After de-molding, all specimens were weighed as shown in Figure 2 and cured in water and Nutrient broth medium at room temperature until the time of test. Control specimens were also prepared in similar way where water was used for mixing. Compression testing was performed as shown in Figure 3 using PACER Automatic Compression Testing Machine.

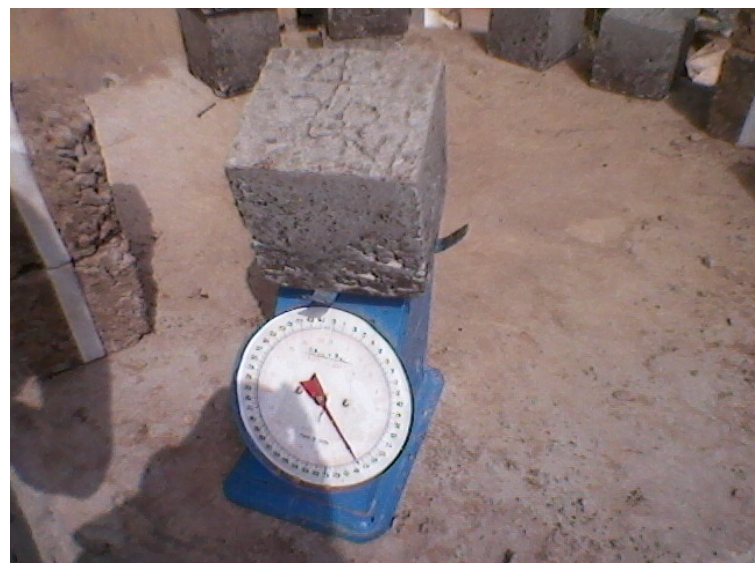

Figure 2. Weighting of a cube sample

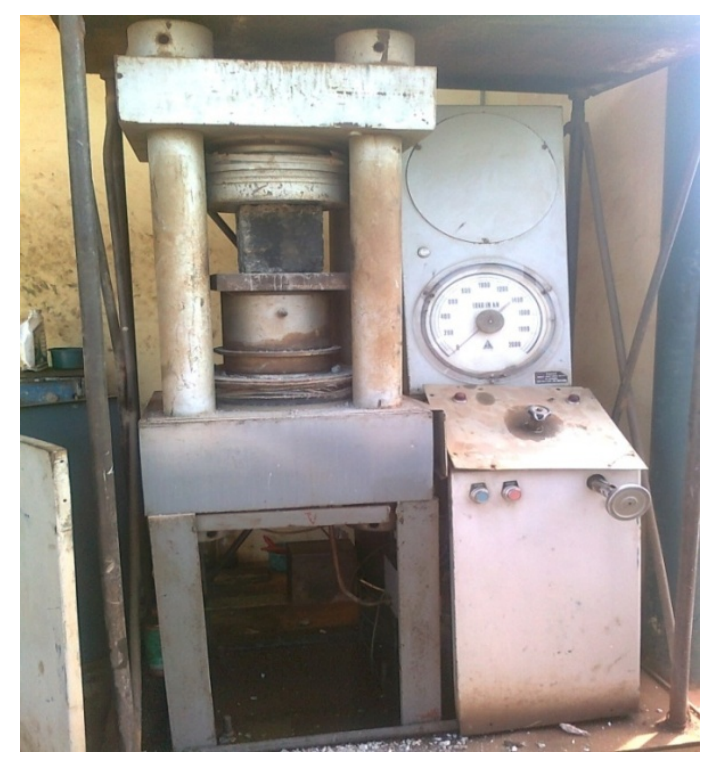

Figure 3. Crushing of a Sample in a Compression Machine

\section{Results and Discussion}

The crushing load of concrete for each curing medium was obtained after 7th, 14th and 28th days of curing and the average crushing load was obtained by the addition of the crushing load for each variation and divided by the total number of cubes of the variation in concern respectively.

Table 4 gives the compressive strength at 7 days, 14 days and 28 days for different water cement ratios of $0.45,0.50$ and 0.55 for control concrete, while Tables 5 and 6 present the summary of compressive strength of laterized concrete at 7 days, 14 days and 28 days for concrete cured in water and in nutrient broth medium for test numbers 1 to 9 . From these tables, it is observed that the compressive strength of concrete for test number 4 with no laterite as aggregate showed a significant increase of $20 \%$ and $41 \%$ for concrete cured in water and nutrient broth medium respectively at 28 days in comparison with control concrete while test number 5 with $20 \%$ laterite replacement gives an increase in compressive strength of $9.6 \%$ and $22 \%$ for concrete cured in water and in nutrient broth medium respectively at 28 days in comparison with control concrete. The Taguchi method gives a clear picture of the importance of each of these factors as shown in Tables 7 and 8 . The orthogonal analysis on compressive strength of microbial laterized concrete with the average effect of each of the factors - W/C, LAT and BM at each of the three levels are represented as - E1, E2, and E3 respectively. For example values under column E1 in Tables 8 and 9 indicate the effect of each factor at level 1 (parameters are indicated in Table 1). From the two tables, the most significant factor $\mathrm{R}$ on the compressive strength at various testing periods is laterite content. It contributed the most effect among the three factors at each of the levels.

Table 4. Compressive strength of conventional concrete for 1:2:4 mix

\begin{tabular}{|c|c|c|c|}
\hline \multicolumn{5}{|c|}{ Days } \\
\hline $\mathrm{W} / \mathrm{C}$ & 7 & 14 & 28 \\
\hline 0.45 & 11.60 & 13.50 & 17.80 \\
\hline 0.50 & 13.00 & 15.00 & 19.80 \\
\hline 0.55 & 12.70 & 14.50 & 18.82 \\
\hline
\end{tabular}

Table 5. Compressive strength of microbial laterized concrete cured in water

\begin{tabular}{|cc|c|c|}
\hline \multicolumn{5}{|c|}{ Days } \\
\hline TEST NO & 14 & 28 \\
\hline 1 & 14.07 & 15.53 & 19.85 \\
\hline 2 & 16.20 & 17.19 & 19.11 \\
\hline 3 & 12.15 & 13.78 & 18.52 \\
\hline 4 & 18.96 & 24.44 & 27.85 \\
\hline 5 & 17.43 & 20.00 & 24.15 \\
\hline 6 & 12.44 & 14.07 & 18.67 \\
\hline 7 & 15.56 & 18.67 & 22.37 \\
\hline 8 & 13.63 & 14.81 & 19.85 \\
\hline 9 & 10.96 & 13.62 & 18.52 \\
\hline \multicolumn{7}{|c|}{} & & \\
\hline
\end{tabular}


Table 6. Compressive strength of microbial laterized concrete cured in nutrient broth medium

\begin{tabular}{|cc|c|c|}
\hline \multicolumn{5}{|c|}{ Days } \\
\hline TEST NO & 14 & 28 \\
\hline 1 & 14.07 & 15.53 & 19.85 \\
\hline 2 & 16.20 & 17.19 & 19.11 \\
\hline 3 & 12.15 & 13.78 & 18.52 \\
\hline 4 & 18.96 & 24.44 & 27.85 \\
\hline 5 & 17.43 & 20.00 & 24.15 \\
\hline 6 & 12.44 & 14.07 & 18.67 \\
\hline 7 & 15.56 & 18.67 & 22.37 \\
\hline 8 & 13.63 & 14.81 & 19.85 \\
\hline 9 & 10.96 & 13.62 & 18.52 \\
\hline
\end{tabular}

Table 7. L9 $\left(3^{3}\right.$ Series $)$ orthogonal analysis on compressive strength of microbial laterized concrete cured in water

\begin{tabular}{|c|c|c|c|c|c|}
\hline & Factors & E1* & E2* & E3* & $\mathrm{R}^{*}$ \\
\hline \multirow{3}{*}{$\begin{array}{c}\text { 7-Day } \\
\text { Compressive } \\
\mathrm{f}_{\mathrm{c}}(\mathrm{MPa})\end{array}$} & $\mathrm{W} / \mathrm{C}$ & 11.08 & 14.20 & 12.27 & 3.12 \\
\hline & LAT & 14.59 & 12.39 & 10.57 & 4.02 \\
\hline & $\mathrm{BM}$ & 11.83 & 12.89 & 12.84 & 1.06 \\
\hline \multirow{3}{*}{$\begin{array}{c}\text { 14- Day } \\
\text { Compressive } \\
\mathrm{f}_{\mathrm{c}}(\mathrm{MPa})\end{array}$} & $\mathrm{W} / \mathrm{C}$ & 13.32 & 16.94 & 14.65 & 3.62 \\
\hline & LAT & 17.15 & 15.04 & 12.73 & 4.42 \\
\hline & BM & 14.17 & 15.33 & 15.41 & 1.24 \\
\hline \multirow{3}{*}{$\begin{array}{c}\text { 28- Day } \\
\text { Compressive } \\
\mathrm{f}_{\mathrm{c}}(\mathrm{MPa})\end{array}$} & $\mathrm{W} / \mathrm{C}$ & 17.28 & 20.87 & 18.84 & 3.59 \\
\hline & LAT & 21.08 & 19.43 & 16.47 & 4.61 \\
\hline & BM & 17.93 & 19.65 & 19.41 & 1.72 \\
\hline
\end{tabular}

Table 8. L9 ( $3^{3}$ Series) orthogonal analysis on compressive strength of microbial laterized concrete cured in nutrient broth medium

\begin{tabular}{|c|c|c|c|c|c|}
\hline & Factors & $\mathrm{E} 1 *$ & $\mathrm{E} 2 *$ & $\mathrm{E} 3 *$ & $\mathrm{R}^{*}$ \\
\hline \multirow{2}{*}{$\begin{array}{c}\text { 7-Day } \\
\text { Compressive } \\
\mathrm{f}_{\mathrm{c}}(\mathrm{MPa})\end{array}$} & $\mathrm{W} / \mathrm{C}$ & 14.10 & 16.40 & 13.48 & 2.92 \\
\cline { 2 - 6 } & $\mathrm{LAT}$ & 16.30 & 15.83 & 11.85 & 4.45 \\
\cline { 2 - 6 } & $\mathrm{BM}$ & 13.38 & 15.34 & 15.26 & 4.45 \\
\hline \multirow{2}{14-\text{Day}}{$\begin{array}{c}\text { Compressive } \\
\mathrm{f}_{\mathrm{c}}(\mathrm{MPa})\end{array}$} & $\mathrm{W} / \mathrm{C}$ & 15.50 & 19.36 & 15.71 & 3.86 \\
\cline { 2 - 6 } & $\mathrm{LAT}$ & 19.56 & 17.33 & 13.68 & 5.88 \\
\hline \multirow{2}{*}{$\begin{array}{c}28-\mathrm{Day} \\
\text { Compressive } \\
\mathrm{f}_{\mathrm{c}}(\mathrm{MPa})\end{array}$} & $\mathrm{W} / \mathrm{C}$ & 18.67 & 23.55 & 20.25 & 4.88 \\
\cline { 2 - 6 } & $\mathrm{BM}$ & 23.35 & 21.04 & 18.07 & 5.28 \\
\cline { 2 - 6 } & 19.46 & 21.82 & 21.18 & 2.36 \\
\hline
\end{tabular}

*E1, E2, E3, - Average effect of three factors at level 1, 2or 3

$* \mathrm{R} \quad-$ Rank of significance among the factors.

BM - Bacteria Medium

LAT - Laterite Content

W/C - Water Cement Ratio
Figures 4 to 6 show the average effect of each of the factors, from which it was observed that the optimum value for water/cement ratio was 0.50 and bacterial medium, $20 \%$, while a negative trend was observed for laterite. However, at $20 \%$ replacement and applying the optimum conditions for water/cement ratio and bacterial medium, laterite can be used in structural concrete as compressive strengths as high as $24 \mathrm{~N} / \mathrm{mm}^{2}$ are achievable.

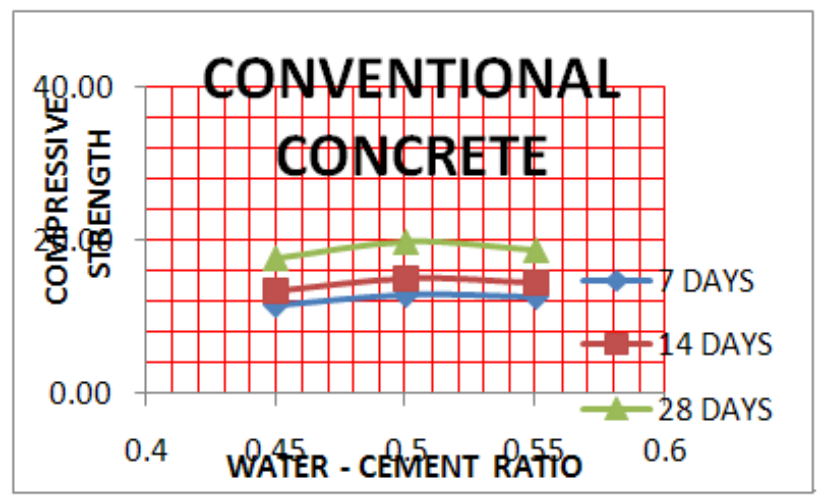

Figure 4. Compressive strength of conventional concrete for 1:2:4 mix

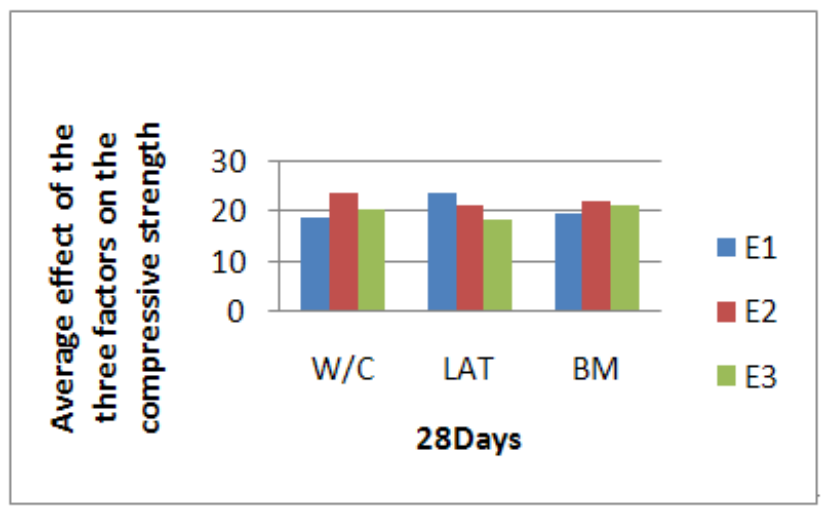

Figure 5. Orthogonal Analysis on Compressive Strength of Microbial Laterized Concrete Cured in nutrrient broth medium

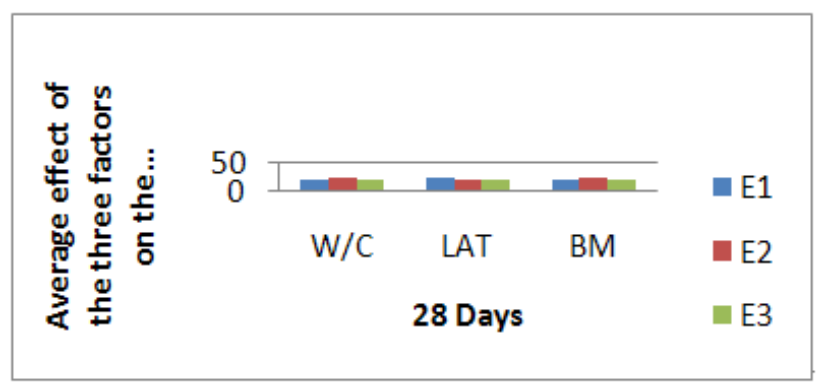

Figure 6. Orthogonal Analysis on Compressive Strength of Microbial Laterized Concrete Cured in water

The improvement in compressive strength by Bacillus sp. JC3 is probably due to the deposition of $\mathrm{CaCO}_{3}$ on the microorganism cell surfaces and within the pores of concrete, which plug the pores within the concrete [15-18] as reported by Achal et al [19].

It was also observed that concrete cubes cured in nutrient 
broth medium had the higher compressive strength which can be attributed to fact that microbial cells was able to get supplementary nutrient from the curing medium.

It is also possible that as the $\mathrm{pH}$ of concrete falls during carbonation, cells become active and as curing period was increased, it started growing slowly. Upon cell growth, calcite would precipitate on the cell surface as well as within the concrete matrix. Thus, the concrete becomes less porous/permeable This explains the behavior of the increased compressive strength at 28 days in concrete cubes prepared with microbial cells with cells either dying or forming protective endospores after some time.

\section{Conclusion}

Based on the present experimental investigation, the following conclusions are drawn:

- It has been generally observed that the addition of laterite to concrete causes a reduction in the compressive strength. However the addition of Bacillus Subtilis JC3 under optimized conditions enhanced the compressive strength of concrete, conventional and laterized alike.

- From the orthogonal analysis on compressive strength, the observed optimum value for water/cement ratio and bacterial medium were 0.5 and $20 \%$ respectively, while a negative trend was observed for laterite replacement.

- At $20 \%$ replacement for sand, laterite can be used in structural concrete as compressive strengths as high as $24 \mathrm{~N} / \mathrm{mm}^{2}$ were attained in 28 days.

\section{REFERENCES}

[1] Shetty M. S. Concrete Technology, S. Chand and Company Ltd, Ram Nagar, New Deihi, 2004.

[2] Adepegba D. The Effect of Water Content on the Compressive Strength of Laterized Concrete, Journal of Testing and Evaluation. 3: 1-5, 1975.

[3] Adepegba D. Structural strength of short, Axially Loaded Columns of Reinforced Laterized Concrete. Journal of Testing and Evaluation. 5: 1-7, 1977.

[4] Lasisi F. and Osunade, J. A. Factors affecting the strength and creep properties of laterized concrete, Building and Environment. 20(2): 133-138, 1985.

[5] Salau M. A. Long-term deformations of laterized concrete short columns. Building and Environment. 38(3): 469-477,
2003.

[6] Jayawardena U. De S. and Dissanayake D.M.S., Use of quarry dust instead of river sand for future constructions in Sri Lanka. IAEG Paper No. 38, 2006.

[7] Jayawardena U. De S. and Dissanayake D.M.S. Identification of the most suitable rock types for manufacture of quarry dust in Sri Lanka, J. Natn. Sci.Foundation Sri Lanka. 36(3): 215-218, 2008

[8] Osadebe N. N. and Nwakonobi T. U. Structural Characteristics of Laterized Concrete at Optimum Mix Proportion, Nigerian Journal of Technology, Nsukka, Nigeria. 26(1): 12-17, 2007.

[9] Ukpata, J. O., Maurice, E. E. and Akeke, G. A. Compressive Strength Of Concrete Using Lateritic Sand And Quarry Dust As Fine Aggregate, ARPN Journal of Engineering and Applied Sciences Vol. 7, No. 1, 2012.

[10] Salau M. A. Abundant Local Structural Engineering Materials without Affordable Structures - An inaugural lecture delivered at the University of Lagos, Nigeria. 23rd April, 2008.

[11] Khan, M. I. Isoresponses for strength, permeability and porosity of high performance Mortar, Building and Environment, 38, 1051-1056, 2003.

[12] British Standard Institute. Portland Cement (Ordinary and Rapid Hardening), BS 12, BSI, London, 1996

[13] Reddy S. P., SheshagiriRao M.V., Aparna P., Sasikala C.H. Performance of standard grade bacterial concrete, Asian Journal of Civil Engineering, 11(1), 43-45, 2010.

[14] Taguchi, G. Introduction to Quality Engineering: Designing Quality into Products and Processes, Asian Productivity Organization, Japan, 1998.

[15] Ramakrishnan, V., Bang, S. S., and Deo, K. S. A novel technique for repairing cracks in high performance concrete using bacteria, Proc. Int. conf. on high performance high strength concrete, Perth, Australia, 597-618, 1998.

[16] Ramachandran, S. K., Ramakrishnan, V., and Bang, S. S. Remediation of concrete using microorganisms, American Concrete Institute Materials J., 98, 3-9, 2001.

[17] Ghosh, P., Mandal, S., Chattopadhyay, B. D., Pal, S. Use of microorganism to improve the strength of cement mortar, Cement and Concrete Research, 35, 1980-1983, 2005.

[18] Achal, V., Mukherjee, A., Basu, P. C., and Reddy, M.S. Lactose mother liquor as an alternative nutrient source for microbial concrete production by Sporosarcinapasteurii, Journal of Industrial Microbiology and Biotechnology, 36,433-438, 2009.

[19] Achal, V., Mukherjee, A., and Reddy, M.S. Microbial concrete: A way to enhance durability of building structures, Journal of the Department of Biotechnology and Civil Engineering, Thapar University, Patiala, Punjab, India, 2010. 